\title{
Lapachol: an overview
}

\section{Hidayat Hussain, ${ }^{* a}$ Karsten Krohn, ${ }^{a}$ Viqar Uddin Ahmad, ${ }^{b}$ Ghulam Abbas Miana, and Ivan Robert Green ${ }^{\text {d }}$}

${ }^{a}$ Department of Chemistry, University of Paderborn, Warburger Straße 100, 33098 Paderborn, Germany

${ }^{b}$ H.E.J. Research Institute of Chemistry, International Center for Chemical and Biological Sciences, University of Karachi, Karachi 75270, Pakistan

${ }^{c}$ Riphah Institute of Pharmaceutical Sciences, Riphah Internation University, Islamabad, Pakistan

${ }^{\mathrm{d}}$ Department of Chemistry, University of the Western Cape, P/Bag X17, Bellville,7530,_South Africa

E-mail: hussain@mail.uni-paderborn.de

\begin{abstract}
Lapachol is a naphthoquinone that was first isolated by E. Paterno from Tabebuia avellanedae (Bignoniaceae) in 1882. A wide spectrum of therapeutic activities have been attributed to lapachol or its derivatives viz., anti-abscess, anti-ulcer, antileishmanial, anticarcinomic, antiedemic, anti-inflammatory, antimalarial, antiseptic, antitumor, antiviral, bactericidal, fungicidal, insectifugal, pesticidal, protisticidal, respiradepressant, schistosomicidal, termiticidal, and viricidal. Originally isolated from species of the Bignoniaceae family, lapachol can also be found in other families such as Verbenaceae, Proteaceae, Leguminosae, Sapotaceae, Scrophulariaceae, and Malvaceae. The interesting and most usefull knowledge on lapachol, which is reviewed in this paper, can be used as a starting point in future research endeavors.
\end{abstract}

Keywords: Lapachol, Tabebuia avellanedae Lor., bignoniaceae, structure, pharmacology, biosynthesis

\section{Contents}

1. Introduction

2. Occurance

3. Structure of lapachol

4. Pharmacological activities

5. Synthesis 
6. Biosynthesis

7. Derivatives

8. Perspectives

\section{Introduction}

Compounds having a quinone as the core system have promising biological activity. A central feature of ortho- and para-quinonoid based cytotoxins is their ability to generate semiquinone radicals by bioreduction, which then accelerates intracellular hypoxic conditions. ${ }^{1,2,3}$ The drug arsenal currently available for fighting against tropical diseases includes many natural and synthetic naphthoquinone derivatives which have been extensively studied due to their ability to interfere with the bio-activities of enzymes known as topoisomerases, ${ }^{3}$ a group of enzymes that are critical for DNA replication in cells. In addition, naphthoquinones have been shown to induce the so-called "reactive oxygen species" that can cause damage to cells. ${ }^{3}$ Since the pioneering work of Wendel ${ }^{4}$ in 1946, who demonstrated that certain naphthoquinones inhibit the growth of Plasmodium vivae, and the work of Fieser et al. in the 1940's, an extensive search for new quinones for use in malaria chemotherapy has started. ${ }^{5}$ Subsequently, quinones have been studied for antitumor, ${ }^{6}$ trypanocidal, ${ }^{7}$ molluscicidal, ${ }^{8}$ leiscmanicidal, ${ }^{9}$ anti-inflammatory ${ }^{10}$ and antifungal $^{11}$ activities. Lapachol 1 (Figure 1) was first isolated from Tabebuia avellanedae (Bignoniaceae) and in the years since the first review on lapachol, published in Portuguese in 2003 in Revista Brasiliera de Farmacia, ${ }^{12}$ there has been a rapid increase in the information available on lapachol.

\section{Occurance}

Lapachol (1) has also been isolated from other families such as Verbenaceae, Proteaceae, Leguminosae, Sapotaceae, Scrophulariaceae, and Malvaceae (Table 1). Among the many significantly biologically active naphthoquinones, lapachol (1) is one of the most versatile biologically active compounds and its presence was sought and found later in several other species $^{13-32}$ and different families as illustrated in Table 1.

\subsection{Tabebuia avellanedae}

Lapachol (1) was first isolated by E. Paterno ${ }^{33}$ from Tabebuia avellanedae in 1882. Tabebuia avellanedae (Figure 2) is a tree from the Bignoniaceae family. Commonly know as "pau d'arco" (alternative name: Lapacho, Pau d'Arco; Taheebo) in Brazil, and its inner bark is used as an analgesic, anti-inflammatory, antineoplasic ${ }^{34}$ and diuretic by the local people in the north eastern parts of Brazil. Its anti-inflammatory, antimicrobial, and antineoplasic activities are cited in the 
literature and is supported by saponines, flavonoides, cumarines, and other natural antibiotics, such as derivatives of lapachol often included among the constituents of the extracted plant material. ${ }^{34}$ The aqueous and methanol extracts of $T$. avellanedae for instance also showed antifungal, antinociceptive and antiedematogenic activities. ${ }^{34}$ Species that contain lapachol and several biogenetically related naphthoquinones (e.g., tahaebo, pau d'arco and lapacho roxo) are widely used in American folk medicine for the treatment of cancer, lupus, infections, wounds, and many other diseases. ${ }^{35}$<smiles>CC(C)=CCC1=C(O)C(=O)c2ccccc2C1=O</smiles>

1

Figure 1. Lapachol (1).

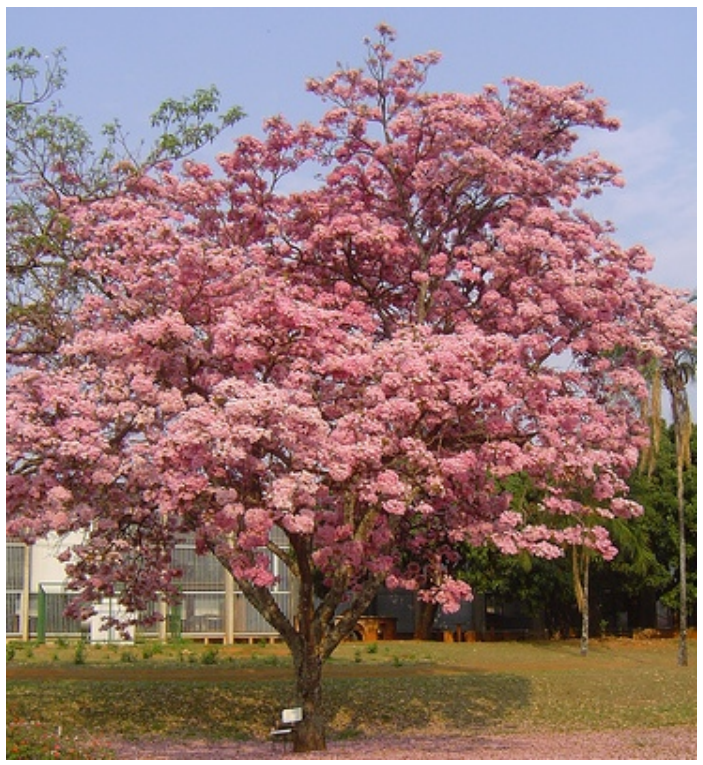

Figure 2. Tabebuia avellanedae. 
Table 1. Occurrence of lapachol in families and species

\begin{tabular}{|c|c|}
\hline Family & Species \\
\hline \multirow[t]{28}{*}{ Bignoniaceae } & Tabebuia flavescens Benth - \& Hook. F. ex. Griseb. \\
\hline & T. guayacan Hemsl. \\
\hline & T. avellanedae Lor. ex Griseb. \\
\hline & T. serratifolia (Vahl.) Nichols \\
\hline & T. rosa \\
\hline & T. bata (E. Mey) Sandw \\
\hline & T. pentaphylla (Linn) Hemls. \\
\hline & T. heptaphylla \\
\hline & Haplophragma adenophylum \\
\hline & Heterophragma adenophylum \\
\hline & Kigelia pinnata \\
\hline & Phyllarthron comorense \\
\hline & Radermachera sinica \\
\hline & Paratecoma peroba (Record) Kuhlm \\
\hline & Tecoma araliaceae DC \\
\hline & T. undulata \\
\hline & Stereospermum suaveolens DC. \\
\hline & S. kunthianum \\
\hline & Zeyhera digitalis \\
\hline & Z. tuberculosa \\
\hline & Millingtonia hortensis Linn \\
\hline & Stereospermum tetragonum DC. \\
\hline & Stereospermumpersonatum \\
\hline & Catalpa longíssima \\
\hline & Cybistax antisyphilitica \\
\hline & Macfadyena ungis-cati \\
\hline & Melloa quadrivalvis \\
\hline & Newbouldia laevis \\
\hline \multirow[t]{3}{*}{ Verbenaceae } & Tectona grandis L. fil \\
\hline & Avicennia tomentosa Jacq \\
\hline & Avicenia officinalis \\
\hline Proteaceae & Conospremum teretifolium $\mathrm{R} . \mathrm{Br}$. \\
\hline Leguminosae & Diphysa robinoide Bent \\
\hline Sapotaceae & Bassia latifolia \\
\hline Malvaceae & Hibiscus tiliaceus \\
\hline Scrophulariaceae & Paulownia kawakamii \\
\hline
\end{tabular}




\section{Structure of lapachol}

Lapachol (1), a yellow coloring matter which occurs in the grain of a number of wooden trees, was suggested by Paterno ${ }^{33}$ to have the structure of an amylene hydroxynaphthoquinone with both substituent groups in the quinone ring (structure 2, Figure 3). After Hooker ${ }^{36}$ had presented convincing reasons for regarding the substance as a derivative of $\alpha$-naphthoquinone, Paterno's structure 2 (Figure 3) remained uncertain only in respect to the position of the double bond in the prenyl side chain. Hooker ${ }^{37}$ then carried out a synthesis of the compound corresponding to 2 by the condensation of isovaleraldehyde with hydroxynaphthoquinone and obtained an isomer of lapachol which however, was regarded as the $o$-quinone isomer of 2 (iso- $\beta$-lapachol) on account of its red color.

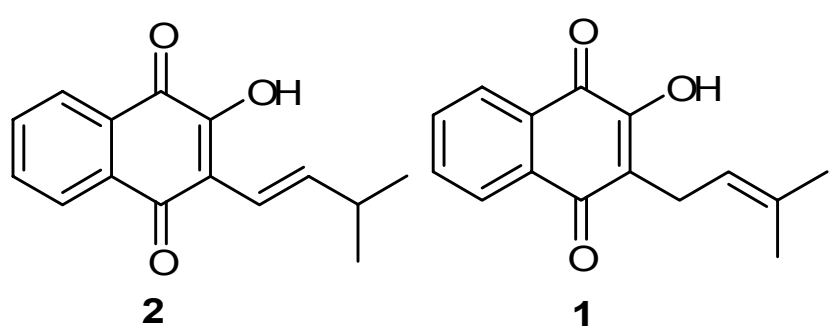

Figure 3. Structures of $i s o-\beta$-lapachol 2 and lapachol 1.

Since the difference between the synthetic and the natural products extended to their hydroquinones, structure 2 could no longer be ascribed to that of lapachol. Of the remaining possibilities, structure 1 was given preference by Hooker, after finding that both lapachol and iso- $\beta$-lapachol could be converted into the same hydroxy compound, having the side chain of $\mathrm{CH}=\mathrm{C}(\mathrm{OH}) \mathrm{CH}\left(\mathrm{CH}_{3}\right)_{2}$. Hooker's structure for lapachol (1) was thus largely influenced by the structure assigned to iso- $\beta$-lapachol, and this cannot be regarded as being established with certainty. Indeed, as a direct consequence, Fieser ${ }^{38}$ undertook a synthesis of the compound corresponding to structure $\mathbf{1}$ by reaction of the silver salt of hydroxynaphthoquinone with $\gamma, \gamma$ dimethylallyl bromide (isoprene hydrobromide). Although the greater part of the silver salt was indeed converted into hydroxynaphthoquinone, a small amount of the normal alkylation product, viz., the 2-alkoxy-1,4-naphthoquinone, was produced together with a small amount of an acidic isomer to which structure 1 was assigned. The latter substance, 2-( $\gamma, \gamma$-dimethylallyl)-3-hydroxy1,4-naphthoquinone, was found to be identical with lapachol by direct comparison with a sample of the natural substance which was kindly furnished by Hooker. 


\section{Pharmacological activities of lapachol and its derivatives}

\subsection{Antitumor activity}

In a 1968 study, lapachol demonstrated highly significant activity against cancerous tumors in rats. $^{39}$ Then in 1974, the NCI reported that Phase I clinical trials failed to produce a therapeutic effect with lapachol without side effects and discontinued further cancer research. ${ }^{40}$ In a small study in 1980 with nine patients with various cancers (liver, kidney, breast, prostate and cervix), pure lapachol demonstrated an ability to shrink tumors and reduce feeling of pain caused by these tumors and achieved complete remissions in three of the patients. ${ }^{41}$ It is believed that the antitumor activity of lapachol may be due to its interaction with nucleic acids. Additionally it has been proposed that interaction of the naphthoquinone moiety between base pairs of the DNA helix occurs with subsequent inhibition of DNA replication and RNA synthesis. ${ }^{42}$

Although lapachol has some beneficial effects, it is by no means a perfect anticancer drug. Despite the lack of significant toxicity even in large oral dose levels, sufficiently high blood levels were not attained to show a therapeutic effect. ${ }^{43}$ This led to the termination of further clinical development of lapachol. Because of its antitumor activity, it is an ideal candidate for systematic modification to develop an understanding of its structure-activity relationships and thus eventually to develop analogs with improved activity.

Hartwell and Abbott reported ${ }^{44}$ that out of 68 synthetic analogs only one, 2-(3,7-dimethyl2,6-octadienyl)-3-hydroxy-1,4-naphthoquinone (3) (Figure 4), was active against the Walker 256 tumor cell line. One year later a study of $\operatorname{Herman}^{43}$ indicated a high activity against the Walker 256 tumor cell line for 2-(3',3'-dibromo-2-propenyl)-3-hydroxy-1,4-naphthoquinone (4). In 1975, Linardi et al. ${ }^{44}$ developed a lapachol analog, 2-(3'-methyl-2-buteny1)-3-(tetraacetyl- $\beta$-Dglucopyranosyloxy)-1,4-naphthoquinone (5), which was effective in increasing the life span by over $80 \%$ in mice inoculated with leukemic cells.

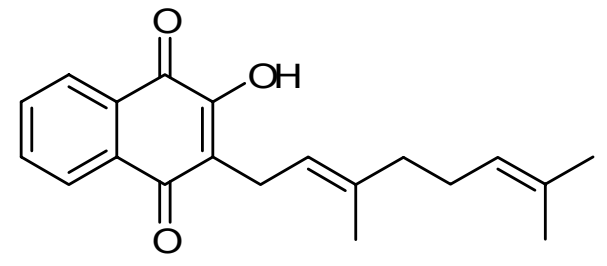

3

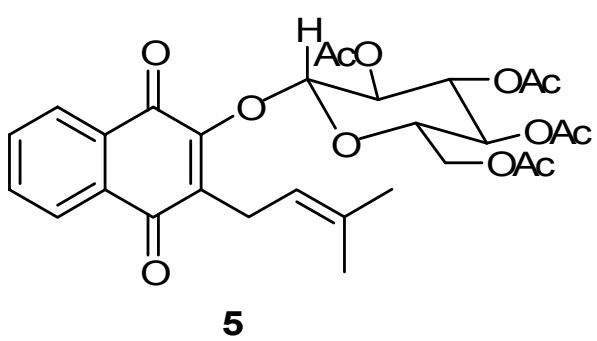<smiles>O=C1C(O)=C(CC=C(Br)Br)C(=O)c2ccccc21</smiles>

4

Figure 4 
Recently, Vargas et al. ${ }^{45}$ synthesized two lapachol derivatives 6 and 7 (Figure 5) and these compounds were active against lung, breast, melanoma, ovarian, prostate, and renal cancer.<smiles>CC(C)CCC1=C(O)C(=O)C2=C(CCCC2)C1=O</smiles>

6<smiles>CC(C)CCC1=C(O)C(=O)c2ccccc2C1=O</smiles>

7

\section{Figure 5}

\subsection{Anti-metastatic activity}

Metastasis is the major process responsible for the death in cancer patients. Balassiano et al. ${ }^{46}$ analyzed the effects of lapachol on a human cancer cell line and evaluated the potential of this substance as an anti-metastatic drug using an in vivo assay. The results of this study indicated that lapachol, in the maximal non-toxic concentration for $\mathrm{HeLa}$ cells of $400 \mu \mathrm{g} / \mathrm{ml}$ (corresponding to $10^{12}$ molecules of the drug/cell), induces alterations in the protein profile and inhibits cellular invasiveness, thus representing an important anti-metastatic activity.

\subsection{Antimicrobial and antifungal activity}

Lapachol, like many napthoquinones, interferes with the electron transport system and inhibits the cell respiratory mechanism. In a study that was done in the 1940's, it was found that lapachol at a concentration of $100 \mathrm{mg} / \mathrm{ml}$, inhibits the uptake of oxygen in Plasmodium Knowles by $74 \%$ and the succinate oxidase system by $26 \%$. These findings lead to the conclusion that lapachol exhibits antimalarial activity against Plasmodium lapohurae via respiratory inhibition as a likely mechanism. However, the exact mechanism of action remains controversial. It is hypothesized that lapachol either inhibits the interaction between the cytochromes b and c or directly inhibits an unknown enzyme between the two cytochromes. ${ }^{42}$ It was also found that lapachol has activity against H. pylori, Staphylococcus, Streptococcus, Enterococcus, Bacillus and Clostridium species with an MIC ranging from 1.56 to $25 \mathrm{mcg} / \mathrm{ml}$. In addition, it was reported that lapachol has a significant effect against Candida albicans, Candida tropicalis, and Cryptococcus neoformans, that was similar to Amphotericin B. The presumed antifungal activity of lapachol is believed to be due to its interaction with the cellular membrane. ${ }^{47-49}$ As part of our systematic search for new bioactive lead structures from African medicinal plants, lapachol has been isolated from Newbouldia laevis and demonstrated antiplasmodial activity as well as antimicrobial activities against some Gram positive and Gram negative microorganisms. ${ }^{19,50,51}$ 
Recently Breger et al. ${ }^{52}$ identified lapachol as being an antifungal agent using the Candida elegans pathogenicity assay.

\subsection{Antiviral activity}

Lapachol was found to be active against certain viral strains including herpes virus types I and II. Naphthoquinones have been documented to show effectiveness against four strains of the flu, polio and vesicular stomatitis virus. Lapachol and its enamine showed larvicidal and insecticidal activity against Artemia salina and Aedes aegypti, respectively and for cytotoxicity against A549 human breast cancer cells. ${ }^{53}$

The mechanism of action of these quinones is supposed to be via DNA and RNA polymerase and retrovirus reveres transcriptase inhibition. Furthermore, $\beta$-lapachone is presumed to interfere with the replication of the HIV-1 virus via transcriptase inhibition. ${ }^{54}$ It is reported that lapachol decreases the replication of viruses in human subjects but as yet there is no available clinical data. $^{54}$

\subsection{Anti-inflammatory activity}

T. avellanedae is believed to have an inhibitory effect on the histamine releasing cells which consequently leads to anti-inflammatory effects. Lapachol, in the preliminary study produced a significant anti-inflammatory action in rats. ${ }^{55}$ According to another in vitro study, lapachol and its analogs were shown to have antipsoriatic effects by inhibiting the growth of human karatinocyte cell line $\mathrm{HaCaT}$ and reducing inflammations. The authors of the study ${ }^{56}$ concluded that lapachol has similar antipsoriatic activity to that of anthralin in inducing damage to the cell membranes of the karatinocyte cells. However, the authors did not report the degree of similarity or difference between the two agents. ${ }^{56}$

\subsection{Antiparasitic activity}

Lapachol has been used as a topical barrier to trematodes specifically Shcistosoma mansion, which causes schistosomiasis. This parasite lives in water and enters the host by penetration through the skin. This pathogen can cause a complicated disease, which can sometimes be fatal. It has also been stated that oral lapachol formulation is effective against skin penetration. In addition, lapachol is claimed to have some effect against Trypanosoma cruzi, which causes trypanosomiasis or Chaga's disease. This disease can be present in either acute or chronic form and has no known cure to date. ${ }^{42}$ However, there is no documented data available in either humans or animal models. Schmeda-Hirschmann ${ }^{57}$ reported the antiparasitic activity of lapachol and related naphthoquinones. 


\subsection{Leishmanicidal activity}

Teixeira et al. in $2001^{9}$ reported that lapachol exhibits marked leishmanicidal activity in vitro. Recently, Lima et al. also reported the antileishmanial activity of lapachol and its derivatives. ${ }^{52,58}$ The mechanism by which lapachol induces lysis of intracellular amastigotes in vitro is not yet clear. However, a characteristic of the naphthoquinones (especially lapachol and $\beta$-lapachone) is that they interfere with the oxygen metabolism of the tumour cell, blocking cell respiration and generating free oxygen radicals. Besides free oxygen radicals, there is evidence that nitric oxide (NO) production, which follows the induction of nitric oxide synthetase by IFN- $\gamma$, plays an important role for the death of intracellular amastigotes in murine macrophages. NO is considered the most important metabolite involved in Leishmania killing in mice. ${ }^{9}$

\subsection{Molluscicidal activity}

Lapachol was assayed for molluscicidal activity against Biomphalaria glabrata and showed significant molluscicidal activity. ${ }^{59}$ The naphthoquinone is bioactivated by $\mathrm{P}_{450}$ reductase into reactive species which in turn promote DNA scission through the generation of superoxide anion radicals by redox cycling.

Silva et al. ${ }^{60}$ and Santana et al. ${ }^{61}$ synthesized derivatives of lapachol for a molluscicidal assay. The partially hydrogenated lapachol derivative 6 (Figure 5), obtained from the catalytic reduction of lapachol, showed molluscicidal activity significantly higher than that of lapachol itself. These findings confirm the importance of lapachol as a pivatol starting material for the production of biologically active compounds. ${ }^{60}$

\subsection{Other miscellaneous activities}

A large number of therapeutic activities have been attributed to lapachol and its derivatives such as the prevention against Schistosoma mansoni cercarial for skin penetration. It was also effective against Biomphalaria glabrata, ${ }^{62}$ embryo alteration in rats, ${ }^{62}$ and showed antioxidant, ${ }^{63}$ cytotoxic (in human Promyelocytic Leukemia HL-60 cell line), ${ }^{64}$ analgesic, ${ }^{65}$ and antipsoriatic activity. ${ }^{65}$

In conclusion, the Phytochemical Database housed at the U.S. Department of Agriculture has documented lapachol as being anti-abscess, anticarcinomic, anti-edemic, anti-inflammatory, antimalarial, antiseptic, antitumor, antiviral, bactericidal, fungicidal, insectifugal, pesticidal, protisticidal, respiradepressant, schistosomicidal, termiticidal, and viricidal. ${ }^{66}$ 


\section{Synthesis}

Fieser's synthesis of lapachol was the first one of this molecule which helped to confirm the structural assignment (see section 3). The early approach employed as terminal step (5\% yield) an alkylation of the silver salt of 2-hydroxy-1,4-naphthoquinone with 1-bromo-3-methyl-2butene (Scheme 1). ${ }^{38}$<smiles>O=C1C=C(O)C(=O)c2ccccc21</smiles><smiles>CC(C)=CC(=O)O[Na]</smiles><smiles>CC(C)=CCC1=C(O)C(=O)c2ccccc2C1=O</smiles>

\section{Scheme 1}

In 1948 Gates and Moesta ${ }^{67}$ reported a synthesis of lapachol by the condensation of leucoisonaphthazarin with isoprene (Scheme 2).<smiles>Oc1c(O)c(O)c2ccccc2c1O</smiles><smiles>C=CC(=C)C(C)C(=O)O[Na]</smiles><smiles>CC(C)=CCC1=C(O)C(=O)c2ccccc2C1=O</smiles>

\section{Scheme 2}

Ten years later Petti and Houghton ${ }^{68,69}$ reported the first practical total synthesis of lapachol with a $35 \%$ overall yield illustrated in Scheme 3 . 
<smiles>O=C1C[C+](O)CC1=O</smiles>

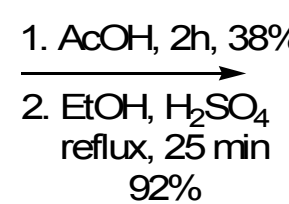<smiles>CCOC(=O)CCC1=C(O)C(=O)c2ccccc2C1=O</smiles><smiles>CCOC(=O)CCc1c(OC(C)=O)c(OC(C)=O)c2ccccc2c1OCC(=O)O</smiles><smiles>CC(C)(O)CCC1=C(O)C(=O)c2ccccc2C1=O</smiles>

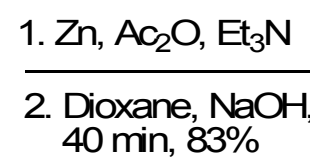<smiles>CC(C)=CCC1=C(O)C(=O)c2ccccc2C1=O</smiles>

\section{Scheme 3}

An interesting alkylation method of lawsone (2-hydroxy-1,4-naphthoquinone) towards a preparative synthesis of lapachol on a large scale was recently reported. ${ }^{70}$ The lithium salt of lawsone was prepared in situ by the addition of lithium hydride to a frozen solution of the quinone in dimethylsulfoxide. As the solution thawed, the lithium salt was slowly formed and it was then alkylated with 3,3-dimethylallyl bromide, to afford the desired lapachol in $40 \%$ yield (Scheme 4).<smiles>O=C1C=C(O)C(=O)c2ccccc21</smiles>

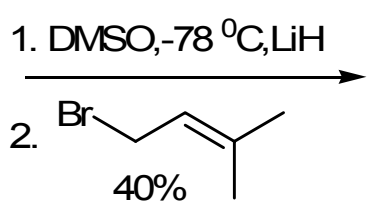<smiles>CC(C)=CCC1=C(O)C(=O)c2ccccc2C1=O</smiles>

\section{Scheme 4}

In an attempt at improving the yield in lapachol synthesis, Kazantzi et al. ${ }^{71}$ recently reported a new synthesis with an overall $43 \%$ yield. In this instance lapachol was prepared by reaction between lawsone and 3-methylbut-2-en-1-ol in the presence of a catalysts such as $\mathrm{Pd}\left(\mathrm{Ph}_{3} \mathrm{P}\right)_{4}$ and 1-admantanecarboxylic acid (Scheme 5). 
<smiles>O=C1C=C(O)C(=O)c2ccccc21</smiles><smiles>CC(C)=CCO</smiles><smiles>CC(C)=CCC1=C(O)C(=O)c2ccccc2C1=O</smiles>

\section{Scheme 5}

In conclusion, the synthesis of lapachol was important for the varification of the structure but is of little practical value when considering the abundance this natural product as a metabolite in several tropical trees.

\section{Biosynthesis}

3-Deoxy-D-arabino-heptulosonate-7-phosphate (DAHP) (10) synthase catalyses the first step in the shikimate pathway (Scheme 6) in which phosphoenolpyruvate (PEP) (8) condenses with Derythrose-4-phosphate (9) in an aldol like fashion, yielding a molecule of 3-deoxy-D-arabinoheptulosonate-7-phosphate (DAHP) (10) and finally form chorismic acid (15). ${ }^{72,73,74}$

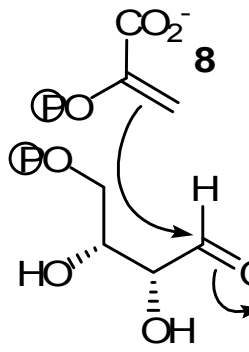

9

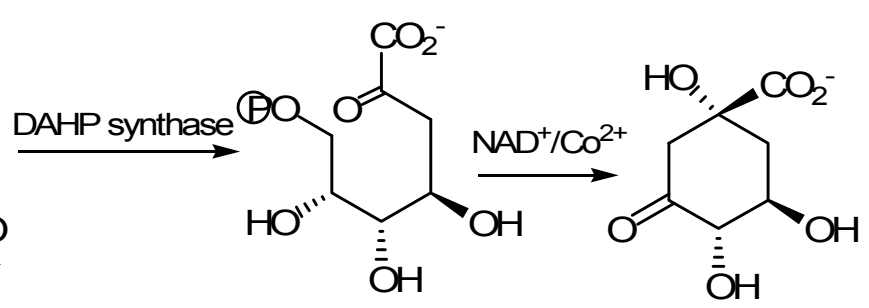

10

11

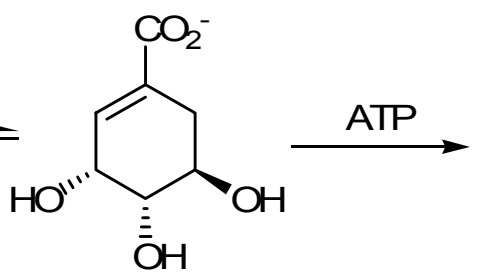

13

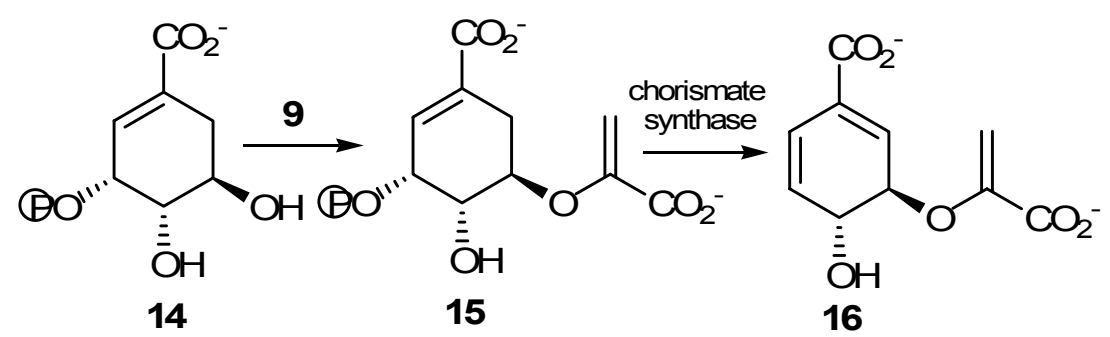

\section{Scheme 5}


A range of naphthoquinone derivatives, including phylloquinone (vitamin $\mathrm{K}_{1}$ ) and menaquinone (vitamin $\mathrm{K}_{2}$ ), are produced from chorismate (16) via isochorismate (17), 2succinoyl-6-hydroxycyclohexa-2,4-diene-1-carboxylate (SHCHC) (22), and orthosuccinoylbenzoate (OSB) (23) (Scheme 6). ${ }^{72}$ The biosynthesis of OSB has been demonstrated for the first time in a Gram-positive bacterium, namely Bacillus subtilis. ${ }^{72}$ Cell extracts were shown to contain isochorismate synthase, the bifunctional SHCHC synthase-2-oxoglutarate decarboxylase, and OSB synthase enzyme activities. ${ }^{72}$<smiles>C=C(O[C@H]1C=C(C(=O)O)C=C[C@H]1O)C(=O)O</smiles><smiles>C=C(C)O[C@H]1C=CC(CCCC(O)C(=O)O)=C(C(=O)O)[C@H]1O</smiles>

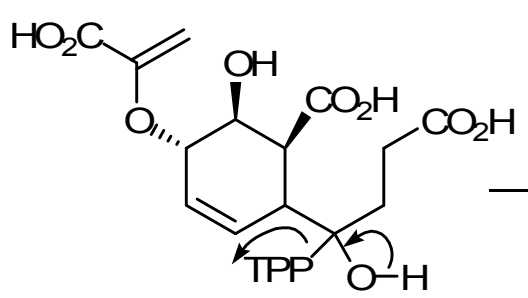

20

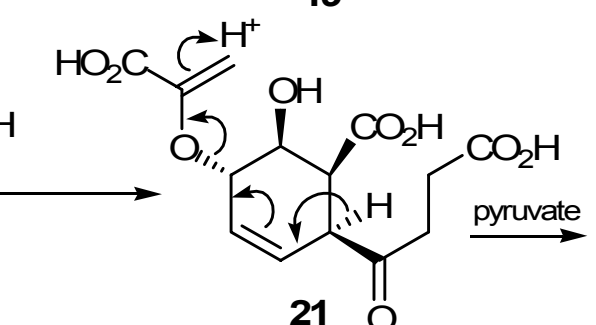

$21 \mathrm{O}$<smiles>O=C(O)CCC(=O)c1ccccc1C(=O)O</smiles>

\section{Scheme 6}

The mode of incorporation of $\left[1-{ }^{13} \mathrm{C}\right] \mathrm{OSB}$ into the naphthoquinone, juglone (27) in Juglans regia seedlings, and into lawsone (25) in Impatiens balsamina plants has been investigated. ${ }^{72}$ Juglone carried approximately $50 \%$ of the label in each carbonyl group, indicating the participation of a symmetrical intermediate, whilst lawsone was specifically labeled at position 1 , demonstrating asymmetrical incorporation (Scheme 7). 1,4-Naphthoquinone (26) is known to be a precursor of juglone, and both $\mathbf{2 6}$ and the glucoside of its quinol form are found in Juglans regia. $^{72}$ Thus, although 1,4-naphthoquinone (26) is therefore a likely intermediate in the 
formation of juglone (27), the decarboxylation and hydroxylation processes in the biosynthesis of lawsone (25) cannot involve this intermediate. ${ }^{72}$

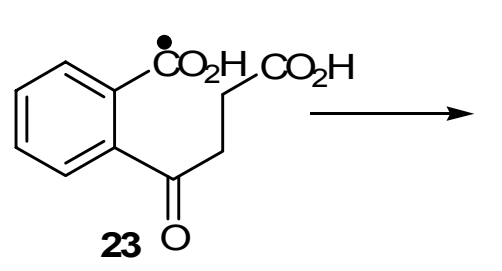

$\bullet={ }^{13} \mathrm{C}$<smiles>[R4]Oc1cc(C)c(O)c2ccccc12</smiles>

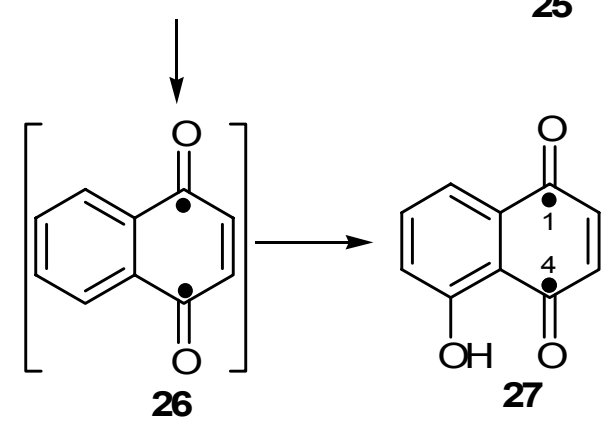

\section{Scheme 7}

Melvalonic acid (28) is well established as the source of prenyl side chains in quinones. It is thus more probable that the prenyl side chain of lapachol is assembeled as a prenyl pyrophosphate (29) which then couples with 2-hydroxynaphthoquinone (25) to form lapachol (1) (Scheme 8).<smiles>CC(C)=CCC1=C(O)C(=O)c2ccccc2C1=O</smiles>

\section{Scheme 8}

\section{Derivatives}

A limited number of natural and semisynthetic derivatives were obtained because the functional groups of lapachol are not sufficiently suitable for structural modification. The first two natural analogues of lapachol to be isolated were $\beta$-lapachone (30) and $\alpha$-lapachone (31) (Figure 6) which were present in Tabebuia avellanedae along with lapachol. ${ }^{47}$ The $\alpha$ - and $\beta$-lapachone were synthesized from lapachol using the Hooker acid catalyzed procedure. ${ }^{22}$ 
<smiles>CC1(C)CCC2=C(O1)c1ccccc1C(=O)C2=O</smiles>

30

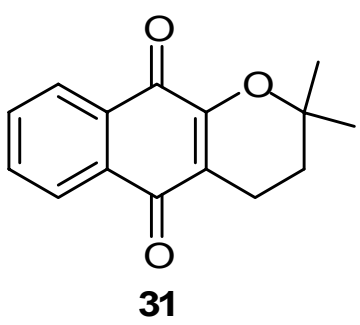

Figure 6. Structure of $\beta$-lapachone (30) and $\alpha$-lapachone (31).

\subsection{Brief History of $\beta$-lapachone}

$\beta$-Lapachone (3,4-dihydro-2,2-dimethyl-2H-naptho[1,2-b]pyran-5,6-dione) (30) is a naturally occurring quinone derived from the lapacho tree, (Tabeuia avellanedae) native to Central and South America. The synthesis and chemistry of $\beta$-lapachone and related compounds was initially investigated in the late $19^{\text {th }}$ and early $20^{\text {th }}$ centuries by the chemist Samuel Hooker. ${ }^{36,37}$ Although some clinical studies on the bioactivity of naphthoparaquinones were reported early in 1940, it was Docampo's report of $\beta$-lapachone's potential as an anti-trypanosomal agent in 1977 that revitalized the study and characterization of this unique natural compound. ${ }^{75}$

Previous studies demonstrated that $\beta$-lapachone can directly target DNA topoisomerases and inhibit their activity, which results in cytotoxicity. ${ }^{76}$ However, its inhibitory mode is quite distinct from that of other typical topoisomerase inhibitors, viz., camptothecin and its related compounds. ${ }^{76} \beta$-Lapachone also exhibits a number of pharmacological actions including antibacterial, anti-fungal, anti-trypanocidal, and cytotoxic activities, which are linked to the formation of reactive oxygen species. ${ }^{76}$

\subsection{Current pharmacological studies of $\beta$-lapachone}

\subsubsection{Anti-angiogenic activity}

Neovascularization is an essential process in tumor development and thus it is conceivable that anti-angiogenic treatment may block tumor growth. ${ }^{77}$ In angiogenesis, nitric oxide (NO) is an important factor which mediates vascular endothelial cell growth and migration. $\beta$-Lapachone has been demonstrated to possess anti-cancer and anti-viral effects. Whether $\beta$-lapachone can induce endothelial cell death or has an anti-angiogenic effect is still uncertain. ${ }^{77}$ Kung et al. ${ }^{77}$ recently investigated the in vitro effect of $\beta$-lapachone on endothelial cells, including the human vascular endothelial cell line, EAhy926, and human umbilical vascular endothelial cells (HUVEC). Kung et al. demonstrated that NO can attenuate the apoptotic effect of $\beta$-lapachone on human endothelial cells and suggest that $\beta$-lapachone may thus have potential as an antiangiogenic drug. ${ }^{77}$ 


\subsubsection{Anti-inflammatory activity}

$\beta$-Lapachone is a chemotherapeutic agent that inhibits the expression of nitric oxide (NO) and inducible NO synthase (iNOS) in alveolar macrophages. Moon et al. ${ }^{78}$ investigated the molecular mechanism of $\beta$-lapachone on lipopolysaccharide (LPS)-induced responses in BV2 microglia. They found that treatment of $\beta$-lapachone significantly inhibited NO and PGE2 release in LPSstimulated BV2 microglia. ${ }^{78}$ The inhibition of iNOS and COX-2 was also observed suggesting the blockage of transcriptional levels. In addition, $\beta$-lapachone attenuated the expression of mRNA and proteins of pro-inflammatory cytokines, such as interleukin (IL)-1 $\beta$, IL-6 and tumor necrosis factor (TNF)- $\alpha$ in a dose-dependent manner. These results showed that $\beta$-lapachone may be useful as a potential anti-inflammatory agent for attenuating inflammatory diseases. ${ }^{78}$

\subsubsection{Anti-tumor activity by activation of the Mre11-Tel1p G1/S checkpoint}

$\beta$-Lapachone is an anticancer agent that selectively induces cell death in several human cancer cell lines. ${ }^{79}$ However the precise mechanism of $\beta$-lapachone cytotoxicity is not yet fully understood. Menacho-Marquez and Mauricio ${ }^{79}$ reported that $\beta$-lapachone treatment delayed cell cycle progression at the G1/S transition, incremented phosphorylation of the Rad53p checkpoint kinase and decreased cell survival in the budding yeast, Saccharomyces cerevisiae. ${ }^{79}$ Furthermore, $\beta$-lapachone induced phosphorylation of histone H2A at serine 129 . These checkpoint responses were regulated by Mec1p and Tel1p kinases. ${ }^{79}$ Mec1p was required for $\operatorname{Rad} 53 \mathrm{p} /$ histone $\mathrm{H} 2 \mathrm{~A}$ phosphorylation and cell survival following $\beta$-lapachone treatment in asynchronous cultures, but not for the G1 delay. The major and vital conclusion of all those findings indicated that $\beta$-lapachone activates a Mre11p-Tel1p checkpoint pathway in budding yeast. Given the conservative nature of the Mre11p-Tel1p pathway, these results suggest that activation of the Mre11-Tel1p checkpoint could be of significance for $\beta$-lapachone anti-tumor activity.

\subsubsection{Use of $\beta$-lapachone in pancreatic cancers}

Erik Bey et al. ${ }^{80}$ discovered that $\beta$-lapachone, currently in phase II clinical trials for use in pancreatic cancers, is also effective against NSCLC (Non-Small Cell Lung Cancer). The authors found that NSCLC cells over express endogenous NAD(P)H:quinone oxidoreductase 1 (NQO1), similar to pancreatic cancers. In NQO1-positive cells, $\beta$-lapachone induced PARP-1-mediated cell death. ${ }^{80}$ Typically, PARP-1 facilitates DNA repair by resealing single strand breaks. When NQO1 is confronted with massive DNA damage, such as after $\beta$-lapachone treatment, it triggers $\mu$-calpain cell death mechanisms. $\beta$-Lapachone was most effective when delivered in short, 2 - to 4-h pulses. Downstream, the chemotherapeutic agent killed NSCLC cells independent of cell cycle or $\mathrm{p} 53$ status and in the absence of proapoptotic factors, according to the authors. ${ }^{80}$

Ough et al. ${ }^{81}$ also found that cytotoxic in vitro effects of $\beta$-lapachone were inhibited with coadministration of dicumarol, a specific inhibitor of NQO1. In pre-established human pancreatic tumor xeno grafts in nude mice, $\beta$-lapachone demonstrated greater tumor growth inhibition when 
given intratumorally compared to when complexed with cyclodextrin to increase its bioavailability. ${ }^{81}$

In another study on $\beta$-lapachone, Park et al. ${ }^{82,83}$ strongly suggested that NQO1 activity in tumors may be further and selectively elevated using either local radiotherapy or hyperthermia, both established cancer treatment modalities, to improve the cytotoxicity of $\beta$-lapachone against human cancer cells. ${ }^{82,83,84}$

\subsubsection{Use of $\boldsymbol{\beta}$-lapachone in treatment of neuroendocrine tumors}

Larsson et al. ${ }^{85}$ studied in vitro drug sensitivity screening using the fluorometric microculture cytotoxicity assay in one human pancreatic carcinoid and two human bronchial carcinoid cell lines. The aim of this study was to investigate drug sensitivity in neuroendocrine tumor cell lines. In addition, a normal human retinal pigment epithelial cell line was used for comparison. A total of 18 drugs, including $\beta$-lapachone, with different mechanisms of action were tested. These studies indicated that some of the tested compounds viz., $\beta$-lapachone, could possibly be used in clinical trials and demonstrate a therapeutic effect in patients suffering with neuroendocrine tumors. $^{85}$

\subsubsection{Selective necrotic cell death by DNA damaging activity}

Most efforts thus far have been devoted to develop apoptosis inducers for cancer treatment. However, apoptotic pathway deficiencies are a hallmark of cancer cells. ${ }^{86}$ Sun et al. ${ }^{86}$ proposed that one way to bypass defective apoptotic pathways in cancer cells is to induce necrotic cell death. They showed that selective induction of necrotic cell death can be achieved by activation of the DNA damage response pathways. While $\beta$-lapachone induces apoptosis through E2F1 checkpoint pathways, necrotic cell death can be selectively induced by $\beta$-lapachone in a variety of cancer cells. Sun et al. ${ }^{86}$ also found that $\beta$-lapachone, unlike DNA damaging chemotherapeutic agents, transiently activates PARP1, a main regulator of the DNA damage response pathway, both in vitro and in vivo. All these data suggested that selective necrotic cell death can be induced through activation of DNA damage response pathways, supporting the idea of selective necrotic cell death as a therapeutic strategy to eliminate cancer cells. ${ }^{86}$

\subsubsection{Use of $\beta$-lapachone in apoptosis induction}

Woo et al. ${ }^{87}$ studied the effects of $\beta$-lapachone on the growth of the human hepatoma cell line HepG2. The results showed that $\beta$-lapachone inhibits the viability of HepG2 by inducing apoptosis, as evidenced by the formation of apoptotic bodies and DNA fragmentation. ${ }^{87}$ Reverse transcription-polymerase chain reactions and immunoblotting results indicated that treatment of cells with $\beta$-lapachone resulted in down-regulation of anti-apoptotic Bcl-2 and Bcl-XL and upregulation of pro-apoptotic Bax expression. However, $\beta$-lapachone treatment did not affect the inhibitor of apoptosis proteins family and the Fas/FasL system. Taken together, this study indicated that $\beta$-lapachone may have potential as a chemopreventive agent for liver cancer. ${ }^{87}$ 
Similarly Woo et al. ${ }^{88}$ also investigated what effect $\beta$-lapachone would have on the cell growth and apoptosis in the human lung carcinoma cell line A549. Exposure of A549 cells to $\beta$ lapachone resulted in growth inhibition and induction of apoptosis in a time- and dose-dependent manner as measured by hemocytometer counts, fluorescence microscopy and flow cytometry anal. These findings provided important new insights into the possible molecular mechanisms of the anti-cancer activity of $\beta$-lapachone. ${ }^{88}$

Lee et al. found that in the micromolar concentration range, $\beta$-lapachone inhibited the viability of human bladder carcinoma $\mathrm{T} 24^{89}$ and human prostate carcinoma DU $145^{90}$ cells by inducing apoptosis, which could be proved by formation of apoptotic bodies and DNA fragmentation. This investigation demonstrated that $\beta$-lapachone may be further studied as a promising agent for treatment of bladder $\operatorname{cancer}^{89}$ as well as providing important new insights into the possible molecular mechanisms of the anti-cancer activity of $\beta$-lapachone. ${ }^{90}$

\subsection{8 $\beta$-Lapachone in combination treatment}

Ablation of tumor colonies has been observed in a wide spectrum of human carcinoma cells in culture after treatment with a combination of $\beta$-lapachone and taxol, two low molecular mass compounds. ${ }^{91}$ They synergistically induced death of cultured ovarian, breast, prostate, melanoma, lung, colon, and pancreatic cancer cells. This combination therapy has unusually potent antitumor activity against human ovarian and prostate tumor prexenografted in mice. ${ }^{91}$ Kumi-Diaka et al. ${ }^{92}$ studied the genistein and $\beta$-lapachone combination treatment to examine the role of NQOI in the signaling of genistein- and $\beta$-lapachone-induced apoptosis in human prostate carcinoma cells PC3.

\subsection{Reaction of lapachol in pyridine}

Jassbi et al. ${ }^{93}$ isolated lapachol from heartwood shavings of Heterophragma quadriloculare and found it to be the most abundant naphthoquinone. To investigate the pyridine catalyzed product of lapachol, the main pigments in the H. quadriloculare plant, Jassbi et al. ${ }^{94}$ heated lapachol (1) in pyridine under reflux (Scheme 9) and isolated quadrilone (32), dehydro- $\alpha$-lapachone (34), and adenophyllone (33). Dehydro- $\alpha$-lapachone (xiliodone, 34) has also previously been synthesized from lapachol by $\mathrm{FeCl}_{3}$ oxidation in the presence of pyridine, acetic anhydride and xilidione and was reported to have an antibiotic effective against Gram negative bacteria of the genus Brucella. ${ }^{93}$ Adenophyllone (33) is a naphthoquinone previously isolated by Jassbi et al. ${ }^{93}$ from Heterophragma adenophyllum. The detailed mechanism describing the formation of compounds 32-34 has been described by Jassbi et al. ${ }^{94}$ and is shown in Schemes 10 and 11. 


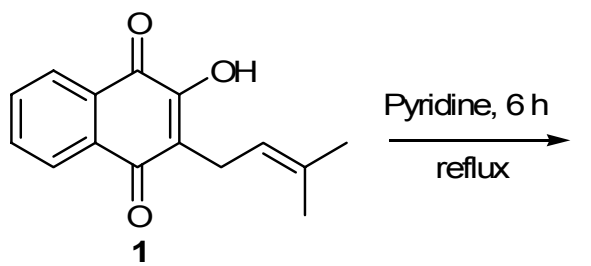<smiles>CC=C(C)C</smiles><smiles></smiles>

33

Scheme 9. Pyridine catalyzed reactions of lapachol.<smiles>CC(C)=CCC1=C(O)C(=O)c2ccccc2C1=O</smiles><smiles>CC1C=CCCC1OC1=CC(=O)c2ccccc2C1=O</smiles>

36<smiles>CCCCC1=CC(C)(C)Oc2c1c(O)c1ccccc1c2O</smiles>

40<smiles>CC(C)=CCNC#N</smiles>

37 38

$-\mathrm{H}_{2} \mathrm{O},-\mathrm{H}$<smiles></smiles>

32

Scheme 10. Suggested mechanism for the formation of qaudrilone (32) ${ }^{94}$ The nucleophile may be pyridine or a conjugated base of a hydroxynaphthoquinone. 
<smiles>CC(C)C(C)C(C)C(C)(C)O</smiles>

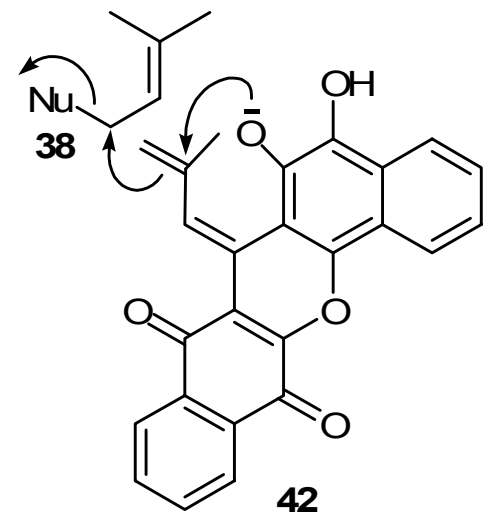

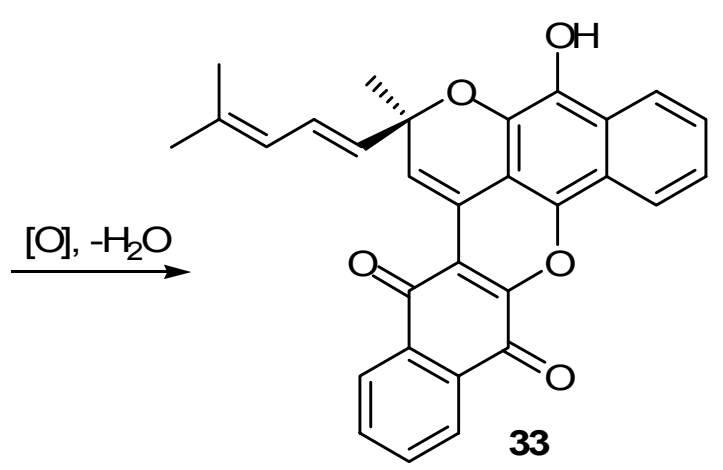

Scheme 11. Suggested mechanism for the formation of adenophyllone (33). ${ }^{94}$

\section{Perspectives}

An evaluation of the therapeutic effects of lapachol started in the late 1960s by Rao, McBride and Oleson. After this study, many others confirmed the efficacy of this naphthoquinone as an antineoplastic agent. However, in 1974, the National Cancer Institute concluded that, due to the high concentrations necessary for this drug to act as an effective chemotherapeutic agent in human cancer which unfortunately also resulted in very toxic side effects, suspension of further studies on the action of lapachol as an antineoplastic agent would be terminated. However, none of these studies considered the effects of lapachol at a molecular level. This information forms the basis to develop the synthesis of new and novel lapachol analogues which can be used as the future starting point in future developments of this potentially potent biological molecule.

\section{References and Notes}

1. Salmon-Chemin, L.; Buisine, E.; Yardley, V.; Kohler, S.; Debreu, M.-A.; Landry, V.; Sergheraert, C.; Croft, S. L.; Krauth-Siegel, R.L.; Davioud-Charvet, E. J. Med. Chem. 2001, $44,548$. 
2. Babior, B. M. Braz. J. Med. Biol. Res. 1997, 30, 141.

3. Da Silva, M. N.; Da Souza, M. C. B. V.; Ferreira, V. F.; Pinto, A. V.; Pinto, M. C. R. F.; Solange M. S. V. Wardell, S. M. S. V.; Wardell, J. L. Arkivoc 2003, 156.

4. Wendel, W. B. 1946. Fed. Proc. 1946, 5, 406.

5. Fieser, L. F.; Berligner, E.; Bondhus, F. J; Chang, F. C.; Dauben, W. G.; Ettlinger, M. G.; Fawaz, G.; Fields, M.; Fieser, M.; Heildelberger, C.; Heymann, H.; Seligman, A. M.; Vaughan, W. R.; Wilson, A. G.; Wilson, E.; Wu, M.-I.; Leffler, M. T.; Hamilin, K. E.; Hathaway, R. J.; Matson, E. J.; Moore, E. E.; Moore, M. B.; Rapala, R. T.; Zaugg, H. E. J. Am. Chem. Soc. 1948, 70, 3151.

6. Subramanian, S.; Ferreira, M. M. C.; Trsic, M. A. Struct. Chem. 1998, 9, 47.

7. Pinto, C. N.; Dantas, A. P.; De Moura, K. C. G.; Emery, F. S.; Polequevitch, P. F.; Pinto, M. C. F. R.; De castro, S. L.; Pinto, A. V. Arzneim. Forsc./Drug Res. 2000, 50, 1120.

8. Santos A. F.; Ferraz, P. A. L.; Pinto, A.V.; Pinto, M. C. F. R.; Goulart, M. O. F.; Sant'Ana, A. E. G. Int. J. Parasitol. 2000, 30, 1199.

9. Teixeira, M. J.; Almeida, Y. M.; Viana, J. R.; Holanda Filha, J. G.; Rodrigues, T. P.; Prata, J. R. C. Jr.; Coelho, I. C. B.; Rao, V. S.; Pompeu, M. M. L. Phytoterapy Res. 2001, 15, 44.

10. Almeida, E.R. J. Ethnopharmacology 1990, 29, 239.

11. Garnier, S.; Wolfender, J.-L.; Nianga, M.; Stoeckli-Evans, H.; Hostettmann, K. Phytochemistry 1996, 42, 1315.

12. Fonseca, S. G. C., Braga, R. M. C.; Santana, D.P. Rev. Bras. Farm. 2003, 84, 9.

13. Colman de Saizarbitoria, T.; Anderson, J. E.; Alfonso, D.; McLaughlin, J. L. Acta Cient Venez. 1997, 48, 42.

14. Duarte, D. S.; Dolabela, M. F.; Salas, C.E.; Raslan, D. S.; Oliveiras, A. B.; Nenninger, A.; Wiedemann, B.; Wagner, H.; Lombardi, J.; Lopes, M.T. J Pharm. Pharmacol. 2000, 52, 347.

15. Ito, C.; Katsuno, S.; Kondo, Y.; Tan, H. T.; Furukawa, H. Chem. Pharm. Bull. 2000, 48, 339.

16. Shetgiri, N. P., Kokitkar, S. V., Sawant, S. N. Acta Pol. Pharm. 2001, 58, 133.

17. Sagrero-Nieves, L. J. Nat. Prod. 1986, 49, 547.

18. Thomson R. H. "Naturally Occurring Quinones III. Recent Advances," Chapman and Hall, London, 1987.

19. Eyong, K. O.; Krohn, K.; Hussain, H.; Folefoc, G. N.; Nkengfack, A. E.; Schulz, B.; Hu, Q. Chem. Pharm. Bull. 2005, 53, 616.

20. Moreira, R. Y. O.; Arruda, M. S. P.; Arruda, A. C.; Santos, L. S.; Muller, A. H.; Guilhon, G. M. S. P.; Santos, A. S.; Terezo, E. Rev. Bras. Farmacog. 2006, 16, 392.

21. Jassbi, A. R.; Mehrdad, M.; Eghtesadi, F.; Ebrahimi, S. N.; Baldwin, I. T. Chem. Biodivers. 2006, 3, 916.

22. de Sousa, J. R.; Silva, G. D. F.; Miyakoshi, T.; Chen, C-L. J. Nat. Prod. 2006, 69, 1225. 
23. Pereira, E. M.; Machado, T. B.; Leal, I. C. R.; Jesus, D. M.; Damaso, C. R. A.; Pinto, A. V.; Giambiagi-de Marval, M.; Kuster, R. M.; Netto, S.; Katia R. Ann. Clin. Microbiol. Antimicrobial 2006, 5.

24. Park, B-S.; Lee, H-K.; Lee, S-E.; Piao, X-L.; Takeoka, G. R.; Wong, R. Y.; Ahn, Y-J.; Kim, J-H. J. Ethnopharmacol. 2006, 105, 255.

25. Rodrigues, A. M. S.; de Paula, J. E.; Roblot, F.; Fournet, A.; Espindola, L. S. Fitoterapia 2005, 76, 755 .

26. Kumar, U. S.; Tiwari, Ashok, K.; Reddy, S. V.; Aparna, P.; Rao, R. J.; Ali, A. Z.; Rao, J. M. J. Nat. Prod. 2005, 68, 1615.

27. Lima, C. S. A.; Amorim, E. L. C.; Nascimento, S. C.; Araujo, C. F.; Agra, M. F.; BarbosaFilho, J. M.; Silva, M. S.; Da-Cunha, E. V. L.; Vieira, I. J. Curcino.; Braz-Filho, R. Nat. Prod. Res. 2005, 19, 217.

28. Park, B.-S.; Kim, J-R.; Lee, S-E.; Kim, K. S.; Takeoka, G. R.; Ahn, Y-J.; Kim, J-H. J. Agr. Food Chem. 2005, 53, 1152.

29. Velasquez, J.; Rojas, L. B.; Usubillaga, A. Ciencia 2004, 12, 64.

30. Huang, P.; Karagianis, G.; Wei, S.; Waterman, P. G. Biochem. Syst. Ecol. 2004, 32, 1047.

31. Schmeda-Hirschmann, G.; Papastergiou, F. Z. Naturforsch. 2003, 58c, 495.

32. Viana, L. M.; Freitas, M. R.; Rodrigues, S. V.; Baumann, W. Braz. J. Chem. Eng. 2003, 20, 317.

33. Paterno, E. Gazz. Chim. Ital. 1882, 12, 337-392.

34. Miranda, F. G. G.; Vilar, J. C.; Alves, I. A. N.; Cavalcanti, S. C. H.; Antoniolli, A. R. BMC Pharmacology 2001, 1, 6 .

35. Sacaua, E. P.; Estevez-Braun, A.; Ravelo, A.G.; Esteban A. Ferro, E.A.; Tokuda, H.; Mukainakac, T.; Nishinoc, H. Biorg. Med. Chem. Lett. 2003, 11, 483.

36. Hooker, S.C. J. Chem. Soc. 1892, 61, 611.

37. Hooker, S. C. J. Chem. Soc. Transactions 1896, 691355.

38. Fieser, L. F. J. Amer. Chem. Soc. 1927, 49, 857-864.

39. Rao, K. V.; McBride, T. J.; Oleson, J. J. Cancer Res. 1968, $28,1952$.

40. Block, J.B.; Serpick, A. A.; Miller. W.; Wiernik, P.H. Cancer Chemother. Rep. 1974, 4, 27.

41. Santana, C. F.; Lins, L. J. P.; Asfora, J. J.; Melo, A. M.; Lima, G.; D’Albuquerque, I. L. P Revista do Instituto de Antibioticos 1980, 20, 61.

42. Murray, M. T.; Pizzorno, J. E., 1998. Encyclopedia of natural medicine $2^{\text {nd }}$ ed. PA4 Rocklin, CA: Prima Pub., 967-972.

43. Block, J. B.; Serpick, A. A.; Miller, W. Cancer Chemother Rep. 1974, 4, 11.

44. Linardi, M. C. F.; Oliveira, M. M.; Sampaio, M. R. P. J. Med. Chem. 1975, 18, 1159.

45. Vargas, M. D.; Pinto, A. C.; Camara, C. A.; Ernesto de Carvalho, J.; Kohn, L. K. Braz. Pedido PI 2007, 21.

46. Balassiano, I. I.; Paulo, S. A.; Silva, N. H.; Cabral, M. C.; Carvalho, M. C. Oncology Reports 2005, 13, 329. 
47. Nagata, K.; Hirai, K.-I.; Koyama, J.; Wada, Y.; Tamura, T. Atimicrob. Agents Chemther. 1998, 42, 700 .

48. Guiraud, P.; Steiman, R.; Campos-Takaki, G-M.; Seigle-Murandi, F.; Buochberg, M.S. Planta Medica 1994, 60, 373.

49. Portillo, A.; Vila, R., Freixa, B.; Tomás Adzet, T.; Canigueral, S. J. Ethnopharmacology 2001, 76, 93.

50. Eyong, K. O.; Folefoc, G. N.; Kuete, V.; Beng, V. P.; Krohn, K.; Hussain, H.; Nkengfack, A. E.; Saeftel, M.; Salem Ramadan Sarite, S. R.; Hoerauf, A. Phytochemistry 2006, 67, 605.

51. Kuete, V.; Eyong, K. O.; Beng, V. P.; Folefoc, G. N.; Hussain, H.; Krohn, K.; Nkengfack, A. E. Pharmazie 2007, 62, 552.

52. Breger, J.; Fuchs, B.B.; Aperis, G.; Moy, T. I. ; Ausubel, F. M.; Mylonakis, E. Plos. Pathogens. 2007, 3, 168.

53. Oliveira, M. F.; Lemos, Telma, L. G.; De Mattos, M. C.; Segundo, T. A.; Santiago, G. M. P.; Braz-Filho, R. An. Acad. Bras. Cienc. 2002, 74, 211.

54. Li, C.J.; Zhang, L. J.; Dezube, B. J.; Crumpacker, C.S.; Pardee, A.B.. Proc. Natl. Acad. Sci. 1993, 90, 1839.

55. Rodrigues de Almeida, E.; Alves da Silva, F. A.; Rodrigues dos Santos, E.; Lopes, C. A. C. J. Ethnopharmcol. 1990, 29, 239.

56. Muller, K.; Andreas Sellmer, A.; Wiegrebe, W. J. Nat. Prod. 1999, 62, 1134.

57. Schmeda-Hirschmann, G.; Papastergiou, F. Z. Naturforsch. 2003, $58 c, 495$.

58. Lima, N. M. F.; Correia, C. S.; Leon, L. L.; Machado, G. M. C.; Madeira, M. F.; Santana, A. E. G.; Goulart, M. O. F. Mem. I. Oswaldo Cruz 2004, 99, 757.

59. Limaa, N. M. F.; Correiaa, C. S.; Ferraza, P. A. L.; Pintob, A. V.; Pintob, M. C. R. F.; Santanaa, A. E. G.; Goular, M. O. F. J Braz. Chem. Soc. 2002, 13, 822.

60. Silva, T. M. S.; Camara, C. A.; Barbosa, T. P.; Soares, A. Z.; Cunha, L. C.; Pinto, A. C.; Vargas, M. D. Bioorg. Med. Chem. 2005, 13, 193.

61. Santana, A. E. G.; Goulart, M. O. F.; Dos Santos, A. F.; Ferraz, P. A. L.; De Abreu, F. C.; Lima, N. M. F.; Chiari, E. Proc. Phyt. Soc. Europe 2002, 47, 255.

62. Maganha, J.; Rocha, E. S.; Brandao, M. A. F.; Peters, V. M.; Guerra, M. O. Braz. Arch. Biol. Techn. 2006, 49, 927.

63. Wenceslau, J. P. S.; Souza, D. F.; Oliveira, M. C. F.; Lemos, T. L. G.; Sousa, A. L.; Trevisan, M. T. S.; Mattos, M. C. Nat. Prod. Comm. 2006, 1, 661.

64. Perez-Sacau, E.; Diaz-Penate, R. G., Estevez-Braun, A.; Ravelo, A. G.; Garcia-Castellano, J. M.; Pardo, L.; Campillo, M. J. Med. Chem. 2007, 50, 696.

65. Felicioa, A. C.; Changa, C. V.; Brandaob, M. A.; Petersa, V. M.; Guerraa, M. O. Contraception 2002, 66, 289.

66. Beckstrom-Sternberg, S.M.; Duke, J.A. 1994. "The Phytochemical Database." ACEDB version 4.3: National Germplasm Resources Laboratory (NGRL), Agricultural Research Service (ARS), U.S. Department of Agriculture.

67. Gates, M.; Moesta, D. L. J. Am. Chem. Soc. 1948, 70, 614. 
68. Pettit, G.R.; Houghton, L. E. Can. J. Chem. 1968, 46, 2471.

69. Pettit, G. R.; Houghton, L.E. J. Chem. Soc. (C) 1971, 46, 509.

70. Sun, J.S.; Geiser, A.H. Tetrahedron lett. 1998, 39, 8221.

71. Kazantzi, G.; Malamidou-Xenikaki, E.; Spyroudis, S. Synlett 2007, 427.

72. Dewick, P. M. Nat. Prod. Rep. 1995, 12, 579.

73. Knaggs, A. R. Nat. Prod. Rep. 2000, 17, 269.

74. Knaggs, A. R. Nat. Prod. Rep. 2003, 20, 119.

75. Docampo, R.; Lopes, J. N.; Cruz, F.S.; Souza, W. Exp Parasitol. 1977, 42, 142.

76. Lee, J. H., Cheong, J. H.; Park, Y. M.; Choi, Y. H. Pharmacol. Res. 2005, 51, 553.

77. Kung, H-N.; Chien, C-L.; Chau, G-Y.; Don, M-J.; Lu, K-S.; Chau, Y-P. J. Cell. Physiol. 2007, 211, 522 .

78. Moon, D-Oh.; Choi, Y. H.; Kim, N-D.; Park, Y-M.; Kim, G-Y. Int. Immunopharmacol. 2007, 7, 506.

79. Menacho-Marquez, M.; Murguia, J. R. Cell Cycle 2006, 5, 2509.

80. Bey, E. A.; Bentle, M. S.; Reinicke, K. E.; Chin-Rang, Y. D.; Girard, Y. L.; Minna, J. D.; Bornmann, W. G.; Gao, J.; Boothman, D. A. Proc. Natl. Acad. USA 2007, 104, 11832.

81. Ough, M.; Lewis, A.; Bey, E. A.; Gao, J.; Ritchie, J. M.; Bornmann, W.; Boothman, D. A.; Oberley, L. W.; Cullen, J. J. Cancer Biol. Ther. 2005, 4, 95.

82. Park, H. J.; Choi, E. K.; Choi, J.; Ahn, K-J.; Kim, E. J.; Ji, I-M.; Kook, Y. H.; Ahn, S-D.; Williams, B.; Griffin, R.; Boothman, D. A.; Lee, C. K.; Song, C. W. Clin. Cancer Res. 2005, $11,8866$.

83. Park, H. J.; Ahn, K-J.; Ahn, S-D.; Choi, E.; Lee, S. W.; Williams, B.; Kim, E. J.; Griffin, R.; Bey, E. A.; Bornmann, W. G.; Gao, J.; Park, H. J.; Boothman, D. A.; Song, C. W. Int. J. Radiat Oncol. 2005, 61, 212.

84. Suzuki, M.; Amano, M.; Choi, J.; Park, H. J.; Williams, B. W.; Ono, K.; Song, C. W. Radiat. Res. 2006, 165, 525.

85. Larsson, D. E.; Loevborg, H.; Rickardson, L.; Larsson, R.; Oeberg, K.; Granberg, D. Anticancer Research 2006, 26, 4125.

86. Sun, X.; Li, Y.; Li, W.; Zhang, B.; Wang, A. J.; Sun, J.; Mikule, K.; Jiang, Z.; Li, C. J. Cell Cycle 2006, 5, 2029.

87. Woo, H. J.; Park, K-Y.; Rhu, C-H.; Lee, W. H.; Choi, B. T.; Kim, G. Y.; Park, Y-M; Choi, Y. H. J. Med. Food 2006, 9, 161.

88. Woo, H. J.; Choi, Y. H. Intl. J. Oncol. 2005, 26, 1017.

89. Lee, J. I.; Choi, D. Y.; Chung, H. S.; Seo, H. G.; Woo, H. J.; Choi, B. T.; Choi, Y. H. Exp. Oncol. 2006, 28, 30.

90. Lee, J. H.; Cheong, J. H.; Park, Y. M.; Choi, Y. H. Pharmacol. Res. 2005, 51, 553.

91. Li, C. J.; Li, Y-Z.; Pinto, A. V.; Pardee, A. B. Proc. Natl. Acad. Sci. USA , 1999, 96, 13369

92. Kumi-Diaka, J.; Saddler-Shawnette, S.; Aller, A.; Brown, J. Cancer Cell International 2004, 4,4 .

93. Jassbi, A. R.; Singh, P.; Jain, S.; Tahara, S. Helv. Chim. Acta 2004, 87, 820. 
94. Jassbi, A. R.; Singh, P.; Lamba, J.; Jain, S.; Baldwin, I. T.; Tahara, S. Z. Naturforsch. 2006, $61 b, 37$.

\section{Authors' Biographical Data}

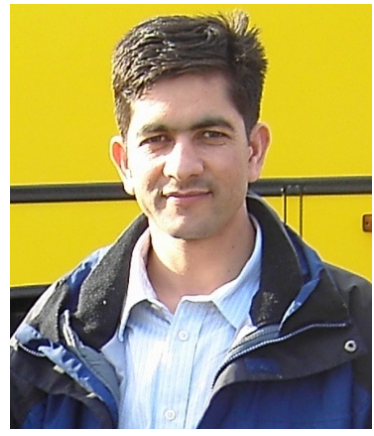

Hidayat Hussain completed his graduation from Gomal University Dera Ismail Khan, Pakistan. He received his $\mathrm{PhD}$ under the supervision of Prof. Viqar Uddin Ahmad in May 2004 from H.E.J. Research Institute of Chemistry, International Center for Chemical and Biological Sciences, University of Karachi, Pakistan. His $\mathrm{PhD}$ work was focussed on Synthesis of Organotin Complexes and Phytochemical Investigation of Euphorbia decipiens. Now he is working as a postdoctoral fellow under the supervsion of Prof. Karsten Krohn at Department of Chemistry, University of Paderborn, Germany from June 2004. His current research interest is focused on the design and synthesis of antimalarial compounds and characterization of natural products produced by endophytic microorganisms, plants and their biological properties.

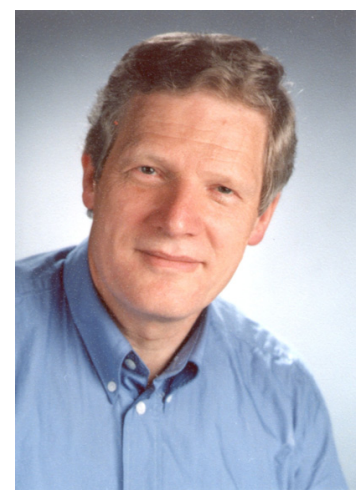

Karsten Krohn was born in 1944 and graduated from the University of Kiel in 1968. He obtained his $\mathrm{PhD}$ in 1971 under the supervision of Professor A. Mondon with a thesis on the isolation and synthesis of alkaloids (narciclasin and lycoricidin) from daffodils. He spent his postdoctoral work first with Professor Mondon and then with Professor Winterfeldt as a DFG stipendiary, working on the synthesis of camptothecin. In 1975 he moved to the University of Hamburg, where he started his work on quinone antibiotics (in particular the anthracyclines) and achieved his Habilitation in 1979. He became Associate Professor at the Technical University of Braunschweig in 1981 and Full Professor in 1991 at the University of Paderborn. In 1984 he was 
Visiting Professor in Madison, Wisconsin, 1996 in Nancy (France), 2001 in Manila (Philippines), and 2006 in Le Mans (France). He is member of several editorial boards of chemical journals (J. Antibiotics, J. Carbohyd. Chem., ARKIVOK). He is Honorary Member of the Hungarian Humbold Society, Fellow of the Japan Society for the Promotion of Science, and Doctor Honoris Causa of the University of Debrecen, Hungary. His research interests are in the isolation and synthesis of natural products from fungi and medicinal plants, synthesis of quinone antibiotics (anthracyclines, angucyclines, anthrapyranes), and the chemistry of sugars (Cglycosides, O-glycosides, conversion of sugars into useful chiral building blocks).

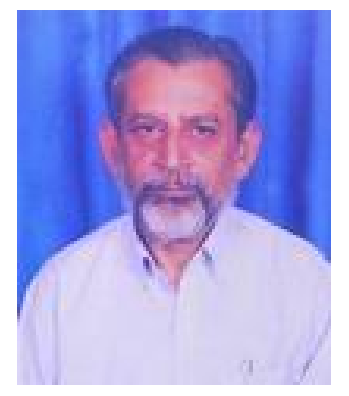

Viqar Uddin Ahmad was born in Meerut, India on July 6, 1940. He did his graduate (Ph. D) studies at University of Karachi, Pakistan. He also did Ph. D (Dr.rer.nat.) in 1968 from Germany. He also awarded D. Sc from University of Karachi in 1992. In 1969 he joined the H.E.J. Research Institute of Chemistry, University of Karachi, where he is currently Professor of Chemistry still active in research. He has directed the research of numerous undergraduate and graduate students in projects related to Natural Product and Synthetic Chemistry. Awarded Alexander Von Humboldt Senior Fellowship in 1975 and worked in Hannover in the laboratories of Prof. E. Winterfeldt upto 1976. Worked as exchange professor in the College of Pharmacy, University of Houston, Houston (Texas, U.S.A.) from 15th of July, 1986 to 14th of August, 1986. Worked as Alexander von Humboldt Fellow in the group of Prof. H. J. Bestmann, Organic Chemistry Institute of the University of Erlangen, Germany, (1.10.1988 to 31.1.1989). Visiting Scientist; Chemistry Department, Cornell University, Ithaca, New York, USA (January-October, 1993). Viqar Uddin Ahmad is an Editor-in-Chief for Journal of Science, University of Karachi and Honourary Co-Editor, Journal of the Chemical Society of Pakistan. Viqar Uddin Ahmad was awarded the Sitara-I-Imtiaz, in 1966; the Hilal-i-Imtiaz in 2006, both by the President of Pakistan. He was also awarded the first Prize of Kharazmi Festival, Awarded by President of Iran, February, 1998. 


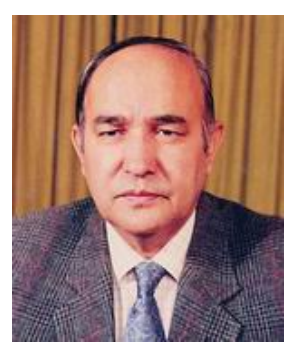

Ghulam Abbas Miana did his graduate studies at University of Calgary, Alberta, Canada (Ph.D. 1967). Work as Postdoctoral Research Fellow: University of Calgary, Alberta, Canada 19701971; Postdoctoral Research Fellow: University of Bonn, Germany, (Humboldt Research Fellow): 1973-1974; Postdoctoral Research: German Cancer Research Centre Heidelberg, Germany (Humboldt Research Fellow) 1976; Postdoctoral Research: Pennsylvania State University, USA 1978-1979; Postdoctoral Research: London School of Pharmacy, University of London, UK 1984. He is rector of Riphah International University, Islamabad, 2000 to date. He was Director, of Hamdard Institute of Pharmaceutical Sciences, Hamdard University, 19992000; Unido Expert on Botanical Pesticides, 1997 (China), 1996 (Thailand), 1990 (Germany). He is Visiting Professor, Institute of Herbal Medicine and Pharmacology, Hamdard University, Karachi, 1998 to date and at HEJ Research Institute of Chemistry, University of Karachi, 1994 to date. Ghulam Abbas Miana was awarded the Sitara-I-Imtiaz, in 1998 by the President of Pakistan.

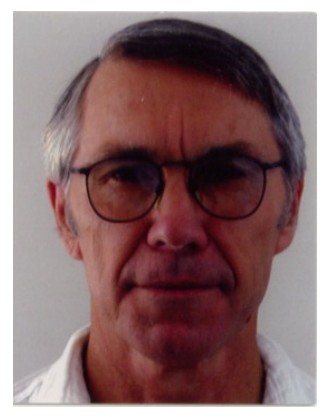

Ivan Robert Green received his $\mathrm{PhD}$ degree from the University of Cape Town, South Africa in 1973 studying under Professor Robin R.G.F. Giles. The work dealt with the synthesis of new and novel naphthoquinones of potential biological importance. He is attached to the University of the Western Cape, South Africa and in his group interests range from the synthesis of naturally occurring quinones having apoptotic and anti-microbial to anti-cancer and anti-tuberculosis activities to the isolation and evaluation of flavanoids having anti-oxidation and anti-mutagenic properties. He regularly referees articles for ARKIVOC, Tetrahedron, European Journal of Organic Chemistry and Synthesis. He has spent several sabbatical visits at Murdoch University and regularly publishes together with a close colleague Prof Giles. He was appointed to full Professor in 1978 and has been Head of the Department for a four year period. Currently he has developed new interests in nanotechnology involving the synthesis of novel catalysts for the Direct Methanol Fuel Cell and a venture into new antibiotics where he is on sabbatical leave at Paderborn University working in the group of Prof K. Krohn. 